\title{
Detection and Control of Invasive Freshwater Crayfish: From Traditional to Innovative Methods
}

\author{
Chiara Manfrin $1, *\left(\mathbb{0}\right.$, Catherine Souty-Grosset ${ }^{2}$, Pedro M. Anastácio ${ }^{3}\left(\mathbb{D}\right.$, Julian Reynolds ${ }^{4,+(\mathbb{C})}$ \\ and Piero G. Giulianini ${ }^{1}$ \\ 1 Department of Life Sciences, University of Trieste, via L. Giorgieri, 5, 34127 Trieste, Italy; giuliani@units.it \\ 2 Laboratoire Ecologie and Biologie des Interactions-UMR CNRS 7267, Equipe Ecologie Evolution Symbiose, \\ Université de Poitiers, 5, rue Albert Turpin, TSA 51106, CEDEX 9, 86073 Poitiers, France; \\ catherine.grosset.souty@univ-poitiers.fr \\ 3 MARE-Marine and Environmental Sciences Centre, Departamento de Paisagem, Ambiente e Ordenamento, \\ Escola de Ciências e Tecnologia, Universidade de Évora, Rua Romão Ramalho, 59, 7000-671 Evora, Portugal; \\ anast@uevora.pt \\ 4 Department of Zoology, Trinity College, University of Dublin, Dublin 2, Ireland; \\ julian.reynolds11@gmail.com \\ * Correspondence: cmanfrin@units.it; Tel.: +39-040-5588734 \\ + Emeritus.
}

Received: 7 November 2018; Accepted: 28 December 2018; Published: 4 January 2019

check for updates

\begin{abstract}
Invasive alien species are widespread in freshwater systems compared to terrestrial ecosystems. Among crustaceans, crayfish in particular have been widely introduced and are considered a major threat to freshwater ecosystem functioning. New emerging techniques for detecting and controlling invasive crayfish and protecting endangered native species are; thus, now highly desirable and several are under evaluation. Important innovations have been developed in recent years for detection of both invasive and native crayfish, mainly through eDNA, which allows for the detection of the target species even at low abundance levels and when not directly observable. Forecasting models have also moved towards the creation of realistic invasion scenarios, allowing effective management plans to be developed in advance of invasions. The importance of monitoring the spread and impacts of crayfish and pathogens in developing national data and research networks is emphasised; here "citizen science" can also play a role. Emerging techniques are still being considered in the field of invasive crayfish control. Although for decades the main traditional techniques to manage invasive crayfish were solely based on trapping, since 2010 biological, biocidal, autocidal controls and sexual attractants, monosex populations, RNA interference, the sterile male release technique and oral delivery have all also been investigated for crayfish control. In this review, ongoing methodologies applied to the detection and management of invasive crayfish are discussed, highlighting their benefits and limitations.
\end{abstract}

Keywords: invasive freshwater crayfish; detection; species control; management; traditional methods; innovative methods

\section{Introduction}

Alien species have been proven to affect ecosystems by leading to the reduction or disappearance of native species as well as causing habitat modification [1-3]. Mediterranean region fresh waters, for example, risk losing $56 \%$ of their endemic freshwater fish, $36 \%$ of freshwater crabs and crayfish, $29 \%$ of amphibians and 19\% of dragonflies over the next decades [4]. Reductions in wetland biodiversity are particularly severe in the Eastern Mediterranean [5], and alien species represent a major threat for developing countries [6]. Alien species can also have impacts on economic activities [7] and can 
strongly affect human health and wellbeing [8-10]. In addition, they are also vectors of pathogens (e.g., Aphanomyces astaci causing crayfish plague), increasing their successful competition against autochthonous species [11,12]. Outbreaks of the crayfish plague were caused by different genotypes of the fungus-like Aphanomyces astaci [13]. The first genotype entered Italy in the 1860s, possibly via infected crayfish being released in ballast waters from a North American ship [14], and the others were repeatedly introduced and spread throughout Europe together with the importation of their natural North American crayfish host species, Orconectes [Faxonius] limosus, Pacifastacus leniusculus and Procambarus clarkii [15].

Today, one of the main effects of globalisation is the ease by which goods are translocated across the globe. Among commercial items, a variety of organic materials may also be accidentally carried and/or may escape and spread in new areas [16]. Crayfish species have social, economic and ecological significance in several regions around the world, favouring their introduction into allochthonous areas [17]. Crayfish have been moved around the world as food, for rearing purposes, and as ornamental pets. P. clarkii is among these successfully and widely intentionally-translocated species [18], and its importance is mainly associated with aquaculture and the aquarium trade, being the most harvested crayfish species in the world and; thus, the most widely spread [17]. Many P. clarkii have escaped from hatcheries and rearing facilities and found natural environments in which to settle [19]. This species has then demonstrated high plasticity in adapting to different environments and temperatures, even far from its optimal thermal conditions [20]. A similar case is that of Cherax destructor, now present in different areas of the globe after escaping from aquaculture [21-24].

Advances in science and application of methodologies from other branches of biology have updated, and in some cases, transformed branches of research linked to the study of ecosystems and invasive species. Undoubtedly, aspects of self-cloning crayfish [25], the development of environmental DNA [26-28], studies on population genetics $[29,30]$ and other approaches from molecular biology [31,32] have increased the limits of detection and expanded the knowledge on the route of spread and physiology of invasive species. Risk analysis and forecasting models along with focused surveillance have proven to foster efficient management actions [33].

In this review, the monitoring systems for the most invasive crayfish species, along with traditional and emerging methods to manage them, are discussed. Particular attention will be paid to innovative techniques applied to their detection and management.

\section{Monitoring the Situation}

Predicting invasiveness, predicting spread, improving detection and control, and bioeconomic analysis to increase cost-effectiveness of management can all be employed to reduce future losses of ecosystem services caused by non-indigenous crayfish species (NICS) [18].

\subsection{Models}

Models are powerful tools to foresee and detect possible invasions at an early stage and are useful to control the spread of invasive crayfish. In the context of the early stages of the invasion process, species distribution models (SDMs) can identify areas that provide suitable environmental conditions for the establishment of invasive crayfish. This approach has been used at scales ranging from local assessments (e.g., river basins) to national [34-37], transnational [38-41] or even worldwide [24,42]. Additionally, model projections can be produced under future scenarios of climate change, analysing possible shifts in areas suitable for the invaders or for the species that these can affect [38,40]. Recently, community-level models (CLMs), that consider multiple co-occurring species have been applied as alternatives to SDMs for analysing and predicting biodiversity patterns [43]. Additionally, risk analysis by SDMs, which link biology and economics, has been used not only in the context of static models (i.e., in which time is not an explicit variable) but also in the context of invasive species dispersal models. 
During the spread stages of a crayfish invasion, spatially-explicit population models (SEPMs) may be useful (i.e., models that consider time and space variables) [44]. These are models in which the distribution and densities of the species are updated as a function of time and space, and predictions can be obtained just as a video showing a shifting distribution map. Several modelling platforms can achieve this purpose, most of them considering population densities per spatial unit over large spatial scales. One example of such use of models of spread in the context of biological invasions, although not specifically with crayfish invaders, is on dispersal surveillance [45]. In spite of this, the usefulness of building SEPMs has been demonstrated for native crayfish [46]. A quite different, spatially explicit approach is the use of individual-based models (IBMs), in which the individuals (and not the populations) are modelled during its lifetime and can, for example, change their location (e.g., by moving, spreading or migrating), can reproduce creating new individuals, or can interact with other individuals of the same species or different species. The difficulty with this approach is that it is much more computationally heavy, and it is usually not applied to large geographical areas.

In the context of understanding species impacts after establishment, the modelling approach is currently applied, for example, to study food web linkages [47]. Other models calculate possible species interactions among crayfish and other species [48,49], although some are only conceptual (i.e., meaning that the interactions among model components are only identified and presented graphically) [50]. It is also important to highlight the numerous applied functions of models (e.g., for the management of invasions), which have been used in several contexts. Some examples are the management of emerging riverine invaders [51] and guiding proactive management of threatened freshwater crayfish [52]. Moreover, the local or regional management of invasive crayfish populations can be aided by population dynamics models and management models. Some models have been proposed to manage invasive crayfish in the wild [53] or in rice field contexts, allowing the calculation of acceptable damage levels and timing for crayfish captures [54-57]. In conclusion, models are excellent tools to forecast, analyse and prepare strategies to deal with crayfish invasions.

\section{2. $e D N A$}

Environmental DNA (eDNA) is a powerful tool for conservation and invasion biology in various environments [58,59], mainly aquatic ones [60-62]. eDNA is defined as "genetic material obtained directly from environmental samples (soil, sediment, water, etc.) without any obvious signs of biological source material", and it is an efficient and non-invasive sampling approach [63]. eDNA analysis allows early detection even when target species are not directly observed. A few studies have estimated the transport distance of eDNA from the source to about $10 \mathrm{~km}$, depending on population size [64,65], and the permanence of genetic material within the environment at about 10 days, indicating that DNA traces are near contemporary with presence of the species $[66,67]$. Compared to traditional survey methods (e.g., trapping and visual surveys), eDNA seems to have higher start-up costs for developing and testing the whole assay (eDNA extraction, PCR condition, primers tests, amplicon sequencing), but a few studies suggest that eDNA can reduce total survey costs $[68,69]$.

This methodology is increasingly being used both in conservation of endangered crayfish species [70-72] and to detect invasive crayfish $[27,73,74]$. For example, eDNA may be applied after a suspected release, when specimens are not numerous enough to be otherwise detected, but they are believed to be present in the environment. Alternatively, it may serve to confirm if an eradication plan has been effective in removing the target NICS. In the recent past, eDNA has been applied in a variety of studies for detecting invasive crayfish species, such as P. clarkii $[28,74,75]$, Faxonius rusticus and P. leniusculus $[71,73,76]$. Crucial in eDNA studies are the sampling methods, in order to avoid contamination and to produce robust and repeatable eDNA results [77]. Technical issues must also be considered to avoid false positives, and are related to possible chimeras (PCR artefacts) produced during the extension step of PCR, and species-specificity of the primers chosen to detect target species. To overcome these possible issues, Sanger sequencing of PCR products has been performed to assign a species identity to the amplicon [63]; however, sequencing is manageable when PCR products range 
between 300-1000 nucleotides. Shorter products (60-80 nucleotides) are being selected for analysis, even partially degraded, and to overcome the impossibility to sequence such short products, a specific labelled probe is used during PCR [75]. These drawbacks can be overcome with good knowledge of assays properties, in silico alignment of species inhabiting the same environment, and well-planned trials, both in laboratory and on-field samples before large-scale application.

Accurate abundance estimation through eDNA is still challenging and depends on multiple factors such as the number of DNA copies released into the water from an individual, the transport rate of the stream and the stability of eDNA over time [65,78]. Moreover, behaviour and season affect crayfish detection and abundance inference using eDNA, as, for example, it has been shown that ovigerous females release higher DNA levels than males do [67]. Therefore, before the application of quantitative eDNA methods, researchers need to quantify the errors generated in order to estimate abundance, depending on many factors, linked both to the target species and to the specific environment studied (i.e., lotic, lentic and ocean waters).

As well as early detection of native or invasive crayfish, eDNA has been used to detect the presence of potential pathogens carried by invasive crayfish. Thus, a crayfish plague has been detected in different water samples by eDNA $[79,80]$. A recent use of eDNA has been eDNA metabarcoding $[78,81]$, used for multiple detection of animals and plants at the community level, and routine applications of this system certainly open up new fields in molecular ecology.

\subsection{Citizen Science, Involving Stakeholders and the Public}

Citizen science is a new approach involving the engagement of the general public in scientific research activities to answer real-world questions, either through their intellectual effort or with their resources and tools [82]. Through voluntary involvement, participants gain new knowledge and skills. Not only do participants provide researchers with experimental data and facilities, but they may also suggest new questions to be answered [83,84]. Information and education are the first step in citizen science, since many species may be present for a long time, even centuries, and thus be thought to be native.

Citizen observation networks aim to involve people in collective monitoring of a territory, thus helping to lower negative impacts on communities and aquatic ecosystems. This approach allows the involvement of local users so that they become key guardians of the territory; it informs users and local populations about issues relating to good environmental status for the years to come, and it provides data sets to support management tools used by decision-makers (municipalities, institutions and managers). Researchers and scientists cannot be constantly present in the field, but through the support of observers, possibly well-trained through dedicated courses, followed by expert validation of the collected sightings, they could cover large areas in almost real time. Often, thanks to dedicated pages on social networks and the development of apps, anyone with a smartphone can help in the battle against invasive crayfish species. Examples are represented by the many pages already on social media focused on or including decapod invasive species, for example, the Facebook pages of the Invasive Species Specialist Group (ISSG), the Washington Invasive Species Council and the NO alle specie alloctone in Italia (NO to the allochthonous species in Italy). Dedicated apps have been developed for invasive crayfish (e.g., http:/ / gamberialieni.divulgando.eu/, https: / /www.facebook. com/MudpuppyNight/, https://scistarter.com/project/495-Craywatch) or for specific geographical areas (e.g., http://www.misin.msu.edu/tools/apps/). Through these portals, people can upload pictures of the invasive species along with the geographical coordinates of where they were observed. Once uploaded, the portal administrator, who is an expert in the field, may validate the picture and make the data publicly available. The result is a map with numbers of observations, along with their pictures. These apps can be constantly updated, and after a certain number of sightings have been validated, the information collected acquires a scientific value and can be used in data analyses.

A recent EU-LIFE funded project, LIFE ASAP (http://lifeasap.eu) is entirely dedicated to increasing the awareness and active participation of citizens on the problem of Invasive Alien Species 
(IAS). Importantly, citizens can; thus, become aware that the release of exotic species into ecosystems is a dangerous action with sometimes severe consequences. It often happens that people, instead of sacrificing crayfish from an aquarium, think that their release is the most compassionate action. Citizen science can help explain the consequences of such actions, even reaching the youngest generations, and contribute to increasing public awareness.

Besides the scientific literature, there are a number of regularly updated databases which provide the most recent information about IAS, such as ISSG: Invasive Species Specialist Group (http:/ / www. issg.org/database/), CIESM: Atlas of Exotic Crustaceans in the Mediterranean (http:/ /www.ciesm. org/atlas/index.html) and ELNAIS: Ellenic Network on Aquatic Invasive Species (https://elnais. hcmr.gr/). It is worth mentioning that the first records of 14 marine IAS in Greek waters $(6 \%$ of the total) are attributed to citizen scientists [85].

\section{Traditional Techniques for Controlling Invasive Crayfish Species}

For decades, the main techniques to manage invasive crayfish have been based on trapping activities [86-88]. However, no physical control methods have proven effective in open systems, such as rivers and streams, when the invasive crayfish species is abundant, ubiquitous and endowed with a high reproductive rate and broad physiological tolerances $[17,89]$. However, in some confined environments, such as lakes or ponds, the abundance of $F$. rusticus has been lowered by baited trapping and fish predation $[47,86]$. These types of intervention often require many years and huge budget investment, which are not always available to management agencies. New controlling methods to slow the proliferation of invasive crayfishes are still needed to guide the allocation of limited resources more effectively and efficiently once a species is already established [51].

Table 1 summarises all the methods for both detecting and controlling invasive crayfish discussed in this manuscript following the authors' opinions on the number of published papers on each considered method.

Table 1. Summary of the methods used to detect and control invasive crayfish species, with a class-level evaluation according to the following criteria: Innovation (method representing new solutions against invasive decapod species), field application (method already applied in the field), applicability (environmental suitability for the application of the method), species-specificity (capacity of the method to specifically target the invasive decapod species), impact (potential ecosystem damages), cost (economic resources requested for the application of the method), efficacy (capacity to manage the target invasive species). + low, ++ medium, +++ high, - not applicable, ? unknown. Updated after Gherardi [90]. Table is based on authors' opinions on numbers of papers published on each method here considered.

\begin{tabular}{|c|c|c|c|c|c|c|c|}
\hline Method & Innovation & $\begin{array}{c}\text { Field } \\
\text { Application }\end{array}$ & Applicability & $\begin{array}{c}\text { Species- } \\
\text { Specificity }\end{array}$ & Impact & Cost & Efficacy \\
\hline \multicolumn{8}{|c|}{ Physical control } \\
\hline Trap & + & +++ & +++ & + & + & +++ & ++ \\
\hline Electroshock & + & +++ & ++ & + & + & +++ & ++ \\
\hline Drainage & + & ++ & + & + & +++ & +++ & ++ \\
\hline Barriers and dams & + & ++ & ++ & ++ & ++ & +++ & ++ \\
\hline \multicolumn{8}{|c|}{ Biological control } \\
\hline Natural predators & ++ & ++ & ++ & ++ & + & ++ & ++ \\
\hline Pathogens & +++ & - & ++ & +++ & $?$ & + & +++ \\
\hline \multicolumn{8}{|c|}{ Biocidal control } \\
\hline Chemicals & + & ++ & + & + & +++ & + & +++ \\
\hline $\begin{array}{c}\text { Natural } \\
\text { substances }\end{array}$ & ++ & ++ & ++ & + & +++ & + & +++ \\
\hline
\end{tabular}


Table 1. Cont.

\begin{tabular}{|c|c|c|c|c|c|c|c|}
\hline Method & Innovation & $\begin{array}{c}\text { Field } \\
\text { Application }\end{array}$ & Applicability & $\begin{array}{l}\text { Species- } \\
\text { Specificity }\end{array}$ & Impact & Cost & Efficacy \\
\hline \multicolumn{8}{|c|}{ Autocidal control } \\
\hline Pheromones & ++ & + & +++ & +++ & + & ++ & + \\
\hline $\begin{array}{c}\text { Monosex } \\
\text { populations }\end{array}$ & +++ & - & ++ & +++ & $?$ & ++ & ++ \\
\hline RNA interference & +++ & - & +++ & ++ & $?$ & + & $?$ \\
\hline SMRT & +++ & + & +++ & +++ & + & +++ & +++ \\
\hline Oral delivery & +++ & - & ++ & $?$ & ++ & ++ & $?$ \\
\hline $\begin{array}{c}\text { Gonopods } \\
\text { removal }\end{array}$ & +++ & ++ & ++ & +++ & $?$ & +++ & $?$ \\
\hline \multicolumn{8}{|c|}{ Monitoring } \\
\hline $\begin{array}{l}\text { Species-distribution } \\
\text { modelling }\end{array}$ & +++ & ++ & +++ & ++ & - & + & ++ \\
\hline eDNA & +++ & ++ & +++ & +++ & + & ++ & +++ \\
\hline Citizen science & ++ & ++ & +++ & +++ & + & + & ++ \\
\hline
\end{tabular}

SMRT: Sterile Males Release Technique; eDNA: environmental DNA.

\subsection{Physical Controls}

The first, and still most often applied, method to control the spread of NICS is their physical control by mass trapping. However, trapping of undesirable species is generally only efficient if combined with other measures to suppress or eliminate populations, such as the use of pheromones extensively applied to insects [91]. An increase in fishing pressure targeting NICS could also be a mitigation measure to control them, along with effective management of ballast waters and the aquarium trade, and utilization of the species as an additive to animal feeds. The human-mediated movement of crayfish around the world follows a multiplicity of pathways that result in either accidental (in ballast or via canals) or deliberate introductions of NICS for aquaculture, stocking, live food commerce, aquarium and pond trade, live bait, biological supply, etc. [92]. However, several studies highlight how intensive harvesting does not eradicate or control crayfish, but; nevertheless, may help in reducing adult populations and minimize some impacts. For several invasive crayfish, trapping acts more as a size-selector, while the smaller remaining individuals take advantage of the lack of competition to grow rapidly [93]. Along with mass trapping, electric screens or fences have been used to control F. rusticus, although with little success; however, with hand removal there was significant reduction of some populations [94]. In the UK, electric shock has been applied to populations of P. leniusculus by means of high intensity ( $96 \mathrm{KW}$, DC current, $1600 \mathrm{~V}$ ), repeated 2-min shocks delivered to a headwater stream for $98 \mathrm{~min}$, resulting in $86 \%$ crayfish mortality. When further 15 -min shocks were delivered for a total of $308 \mathrm{~min}$, mortality rose to $97 \%$. However, this treatment is considered as non-selective control rather than eradication [95].

\subsection{Barriers and Drainage Interventions}

Structural barriers have also been planned and tested to limit the spread of invasive crayfish, while still allowing upstream migration of fish [96] or translocation to ark sites of native imperilled crayfishes [72]. Effectiveness of dam construction to contain the upstream dispersal of invasive P. clarkii has been evaluated over two years, demonstrating their effectiveness in hindering the range extension of P. clarkii [97].

Drainage of ponds is also extensively used, especially in water bodies with dense populations, as well as diversion of rivers and construction of barriers. The efficiency of these methods is not yet confirmed, especially for ponds inhabited by P. clarkii, as this species is resistant to drought due to its burrowing ability $[90,98]$. 


\subsection{Biological Control}

Natural predators have been considered for the control of invasive crayfish, for example, P. clarkii introduced into Spain became the main prey item of pike (Esox lucius), another introduced species [99]. In addition, eels (Anguilla anguilla) have been used to attempt the control of the red swamp crayfish [100], and increased fish predation, along with physical control, has been successfully applied against $F$. rusticus [101]. Natural pathogens have also been considered as candidate biological control agents against NICS [102], such as the P. leniusculus bacilliform virus (PI BV) [103]. It is important to consider possible resistance to the agent by the target invasive crayfish population, and information on the life cycle of the pathogen and its possible effects on the native community is essential.

Up to now, none of these methods seem to have acted efficiently, and some attempts to infect different invasive crayfish have failed, suggesting that the infection may in fact be host-specific [104]. Moreover, introductions of predators may not be environmentally sustainable and they represent new pressures on the already invaded ecosystems. No recent study on NICS management is considering predation to mitigate and control invasive crayfish spread.

\subsection{Biocidal Control}

The target organism may be impacted by the use of chemicals to alter the surrounding environment, for instance, by an increase or decrease in $\mathrm{pH}$ or oxygen concentrations [105]. Pesticides and substances such as rotenone, a naturally occurring ketone, have been used to control crayfish such as F. virilis [106]. However, rotenone is toxic to fish and amphibians at levels lower than those needed to kill crustaceans $[107,108]$. Its use is likely to affect numerous other aquatic taxa $[109,110]$, so rotenone remains contentious, as its impacts on non-target biota are still largely unknown [111-114].

Tests of natural pyrethrum to eradicate P. leniusculus in Scottish ponds were successful after water was first deoxygenated [115]. Elsewhere, a synthetic pyrethroid, named Baythroid, at $25 \mu \mathrm{g} / \mathrm{L}$ was evaluated against $F$. rusticus and shown to be effective both in a pond and in laboratory tests [116]. Natural pyrethrum, directly affecting the physiology of crayfish, has been tested to control P. clarkii in an Italian rural district, but further experiments are needed, as claimed by authors [117]. High, sub-lethal concentrations of metolachlor ( $80 \mathrm{ppb}$ ) may interfere with the olfactory-mediated behaviour of $F$. rusticus to receive or respond to social signals and thus affect certain agonistic behaviours, implications that might be useful in its management [118].

The main limits on the use of chemicals are the effects they can have on both native flora and faunal species. The evolution of resistance, bioaccumulation and biomagnification are also aspects to consider before the use of biocidal control. Substances of this nature may be used in highly compromised situations and in circumscribed areas, such as ponds. In addition, biocide treatment to eradicate unwanted populations must be applied to the whole water-body, so partial dewatering may reduce the cost of biocides. In one experiment, most crayfish vacated exposed burrows at night, but $0.5 \%$ remained in burrows, surviving up to six nights after exposure, and the potential for terrestrial roaming to other sites must also be considered [119].

\section{Emerging Techniques for Controlling Invasive Crayfish and Protecting Endangered Native Species}

Autocidal approaches are based on the target species' biology and; therefore, should not cause environmental contamination nor impact on non-target species [120]. Their use; thus, appears to be a promising control strategy. Integrated pest management (IPM), using a range of control and containment techniques to suit specific sites, is strongly suggested for obtaining best results in the future [90]. 


\subsection{Sexual Attractants}

Chemical signalling is a key component in social interactions of species in aquatic environments, where visibility may be limited by the turbidity or by vegetation in the water. Chemical substances such as pheromones are released by individuals into the environment and they trigger specific, adaptive and innate biological responses in conspecifics. Pheromones are widely used to control insect pests [121], and some attempts have been made with P. leniusculus [122,123] and P. clarkii [124]. Studies by Stebbing and colleagues $[125,126]$ have shown that the sex pheromones of $P$. leniusculus are in fact repellent to native A. pallipes, suggesting that traps baited with sex pheromones would not attract the native species.

In crustaceans, the structures of chemical compounds have yet to be identified, but it seems clear that the pheromone signal is released in the urine of females to which reproductive males respond [122]. Multiple strategies of NICS control could benefit from the use of pheromones to disrupt reproductive success, to divert migrations and to increase reproduction with sterile individuals.

\subsection{Monosex Populations}

A technique studied for both aquaculture and invasive crayfish species is the "masculinization of individuals". The insulin-like androgenic gland hormone (IAG) plays a decisive role in sexual differentiation, with the possibility of manipulating crayfish populations in order to produce sexually altered populations, such as monosex populations, which will not reproduce further $[127,128]$. The potential of intervention through sex-change induction on established populations of NICS illuminates new management possibilities.

\subsection{Silencing of Key Hormones through RNA Interference (RNAi)}

This is another method investigated as a potential technique to interfere with NICS by allowing selective disturbance of the target alien species while reducing adverse effects on native species, even those closely related to the alien species. RNAi refers to the process of exogenous double-stranded RNA (dsRNA) silencing the complementary endogenous messenger RNA, and it might be applied for the control and synchronization of the moult cycle, eradication of invasive species and immune defence [129]. It has been shown that the "knock down" of two crustacean hyperglycaemic hormones could affect the survival of P. clarkii in autocidal-based methods [130]. Furthermore, this method is potentially easily applicable year-round through baits and is inexpensive compared to the costs of trapping, the approach used so far to restrict the spread of invasive P. clarkii [131].

\subsection{Sterile Male Release Technique (SMRT)}

This method is based on the release, into the environment, of sterile males that are sexually active and able to compete with untreated males for mating partners. The SMRT technique has been deemed reliable because it exclusively acts on target species without interacting with existing biomes, while also being safe for human health [132]. It has been successfully applied to P. clarkii where males were subjected to a radiation of $40 \mathrm{~Gy}$ (four times the lethal dose for a human), demonstrably reducing fertility by over 50\% without compromising their vitality [133]. Crayfish that underwent X-ray exposure showed a significant decrease of about $80 \%$ of circulating haemocytes, thus this method affects important functions such as those of the immune system, in addition to altering the gonad tissue [134]. SMRT, in combination with intensive trapping, has proved to be particularly effective in a small lake (Casette lake, Pordenone, Friuli Venezia Giulia, Italy) with about $87 \%$ reduction of $P$. clarkii population after two years of activity [135].

Recent unpublished studies on P. clarkii males that underwent $\mathrm{X}$-ray radiation demonstrated a recovery of immunocompetence and an unaltered behavioural pattern, underlining the suitability of this technique to tackle, for example, the red swamp crayfish invasion [136]. Another related control method being tested is the mechanical removal of gonopods from captive males and their release into the population [137]. 


\subsection{Oral Delivery}

New, user-friendly, cheaper and high-tech autocidal methods are needed for controlling crayfish populations. Among new eradicative methods, a water/oil/water microemulsion is being tested as an autocidal method to convey neuropeptides, which play a role in the control of glycaemia and homeostasis in P. clarkii populations by hampering their physiological state [131]. Oral delivery systems to control invasive crayfish have never been applied in the field up to now, so they represent a new and not entirely investigated management frontier [131].

\section{Conclusions}

Hundreds of freshwater species have been moved outside of their native ranges by vectors such as ballast water, canals, deliberate introductions, and releases from aquaria or garden ponds. Owing to the social, economic and ecological significance of crayfish species in several regions around the world, their introduction into allochthonous areas has been favoured. Furthermore, the ease of global transferability of live specimens, to be sold as food delicacies or ornamental pets, is rapidly increasing their translocations. Fortunately, invasive sciences are emerging, not only within the scientific community but also among citizens, and awareness of the danger of allochthonous species release is now more widespread.

This paper offers a summary of the different methods used to detect and control non-indigenous crayfish species, both traditional and emerging ones. Among emerging techniques for detecting invasive species, undoubtedly eDNA and forecasting models are currently the most promising methods, and the increasing interest in "citizen science" is leading to effective support in general monitoring of alien species. The results obtained from models combined with a panel of other techniques, such as environmental DNA, drones or citizen science, allow more efficient management by focusing surveillance, prevention, eradication and control efforts on the highest-risk species and locations [33]. Models can also be very efficient for preliminary assessment of scenarios and for theoretical testing of management techniques. Moreover, a better understanding of management options as well as joint efforts in educating both the public and decision-makers is crucial for timely action against invasive crayfish and against alien species in general, before they can become invasive.

The efficacy of control and/or eradication actions is correlated with the invasion situation and the characteristics of the invaded water body (lentic or lotic waters, but also open or closed systems). For this reason, new management approaches are needed.

The potential use of SMRT for the management of invasive crayfish has recently been tested $[133,138]$. This technique, although initially expensive, causes no environmental contamination or non-target impacts. The biotechnological methods recently undertaken seem to be more powerful tools for fighting against alien crayfish, as the invasive species have shown unexpected plasticity in their ecology. One of the best studied examples is the ability of red swamp crayfish P. clarkii to live in very different habitats and so it is considered a super-ecological strategist [17].

A clear management response is the need to control the international pet trade, which has led to many invasions of alien crayfish [139]. As a result, many aquatic animals, such as the North American crayfish, have become widespread in Europe and are costly to control. If an integrated management method can be found for invasive crayfish, it is important to keep in mind that associated pathogens, that are among the main impacts of invasive crayfish on native communities, could persist and spread. This is the reason why the prevention of introductions is the main task facing workers.

The prevention and management of the introduction and spread of invasive alien crayfish, and other freshwater alien species, is recognised as vital for the success of control actions and their economic efficiency [140]. Even more importantly, efficient controls of invasive crayfish will facilitate restoration of native biodiversity and thus improve ecosystem diversity, and at the same time act positively towards human health and well-being. 
Author Contributions: All the authors worked equally on the preparation of this review and agree to be personally accountable for their own contributions.

Funding: This research received no external funding.

Conflicts of Interest: The authors declare no conflicts of interest.

\section{References}

1. Richman, N.I.; Böhm, M.; Adams, S.B.; Alvarez, F.; Bergey, E.A.; Bunn, J.J.; Burnham, Q.; Cordeiro, J.; Coughran, J.; Crandall, K.A.; et al. Multiple drivers of decline in the global status of freshwater crayfish (Decapoda: Astacidea). Philos. Trans. R. Soc. Lond. B Biol. Sci. 2015, 370, 20140060. [CrossRef] [PubMed]

2. Hansen, G.J.A.; Hein, C.L.; Roth, B.M.; Vander Zanden, M.J.; Gaeta, J.W.; Latzka, A.W.; Carpenter, S.R. Food web consequences of long-term invasive crayfish control. Can. J. Fish. Aquat. Sci. 2013, 70, 1109-1122. [CrossRef]

3. Deidun, A.; Sciberras, A.; Formosa, j.; Zava, B.; Insacco, G.; Corsini-Foka, M.; Crandall, K.A. Invasion by non-indigenous freshwater decapods of Malta and Sicily, central Mediterranean Sea. J. Crustacean Biol. 2018, 38, 1-6. [CrossRef]

4. Manfrin, C.; Souty-Grosset, C.; Anastácio, P.; Reynolds, J.; Giulianini, P.G. The Apparently Relentless Spread of the Major Decapod Alien Species in the Mediterranean Basin and European Inland Waters. In Histories of Bioinvasions in the Mediterranean; Queiroz, A., Pooley, S., Eds.; Springer Nature: Cham, Switzerland, 2018; Volume 8, pp. 51-86.

5. MWO (Mediterranean Wetlands Outlook). First Mediterranean Wetlands Observatory Report; MWO: Tour du Valat, France, 2012; p. 128.

6. Early, R.; Bradley, B.A.; Dukes, J.S.; Lawler, J.J.; Olden, J.D.; Blumenthal, D.M.; Gonzalez, P.; Grosholz, E.D.; Ibanez, I.; Miller, L.P.; et al. Global threats from invasive alien species in the twenty-first century and national response capacities. Nat. Commun. 2016, 7, 1-9. [CrossRef] [PubMed]

7. Souty-Grosset, C.; Anastácio, P.M.; Aquiloni, L.; Banha, F.; Choquer, J.; Chucholl, C.; Tricarico, E. The red swamp crayfish Procambarus clarkii in Europe: Impacts on aquatic ecosystems and human wellbeing. Limnologica 2016, 58, 78-93. [CrossRef]

8. Souty-Grosset, C.; Anastacio, P.; Reynolds, J.; Tricarico, E. Invasive freshwater invertebrates and fishes: Impacts on human health. In Invasive Species and Human Health; Mazza, G., Tricarico, E., Eds.; CABI: Oxfordshire, UK, 2018.

9. Mazza, G.; Tricarico, E.; Genovesi, P.; Gherardi, F. Biological invaders are threats to human health: An overview. Ethol. Ecol. Evol. 2014, 26, 112-129. [CrossRef]

10. Shackleton, R.T.; Larson, B.M.H.; Novoa, A.; Richardson, D.M.; Kull, C.A. The human and social dimensions of invasion science and management. J. Environ. Manag. 2019, 229, 1-9. [CrossRef] [PubMed]

11. Lodge, D.M.; Taylor, C.A.; Holdich, D.M.; Skurdal, J. Nonindigenous Crayfishes Threaten North American Freshwater Biodiversity: Lessons from Europe. Fisheries 2000, 25, 7-20. [CrossRef]

12. Aquiloni, L.; Martin, M.P.; Gherardi, F.; Diéguez-Uribeondo, J. The North American crayfish Procambarus clarkii is the carrier of the oomycete Aphanomyces astaci in Italy. Biol. Invasions 2011, 13, 359-367. [CrossRef]

13. Vogt, G. Diseases of European freshwater crayfish, with particular emphasis on interspecific transmission of pathogens. In Crayfish in Europe as Alien Species. How to Make the Best of a Bad Situation? Gherardi, F., Holdich, D., Eds.; A.A. Balkema: Rotterdam, The Netherlands, 1999; pp. 87-102.

14. Unestam, T. Significance of diseases in freshwater crayfish. Freshw. Crayfish 1973, 2, 136-150.

15. Gherardi, F. Crayfish invading Europe: The case study of Procambarus clarkii. Mar. Freshw. Behav. Physiol. 2006, 39, 175-191. [CrossRef]

16. Faulkes, Z. The global trade in crayfish as pets. Crustacean Res. 2015, 44, 75-92. [CrossRef]

17. Reynolds, J.; Souty-Grosset, C. Management of Freshwater Biodiversity: Crayfish as Bioindicators; Cambridge University Press: Cambridge, UK, 2012; p. 384.

18. Lodge, D.M.; Deines, A.; Gherardi, F.; Yeo, D.C.Y.; Arcella, T.; Baldridge, A.K.; Barnes, M.A.; Chadderton, W.L.; Feder, J.L.; Gantz, C.A.; et al. Global Introductions of Crayfishes: Evaluating the Impact of Species Invasions on Ecosystem Services. Annu. Rev. Ecol. Evol. Syst. 2012, 43, 449-472. [CrossRef]

19. Gherardi, F.; Acquistapace, P. Invasive crayfish in Europe: The impact of Procambarus clarkii on the littoral community of a Mediterranean lake. Freshw. Biol. 2007, 52, 1249-1259. [CrossRef] 
20. Peruzza, L.; Piazza, F.; Manfrin, C.; Bonzi, L.C.; Battistella, S.; Giulianini, P.G. Reproductive plasticity of a Procambarus clarkii population living $10^{\circ} \mathrm{C}$ below its thermal optimum. Aquat. Invasions 2015, 10, 199-208. [CrossRef]

21. Berné, L.B. Primera cita de Cherax destructor (Crustacea: Decapoda: Parastacidae) em España. Bol. SEA 1996, 14, 49-51.

22. Scalici, M.; Chiesa, S.; Gherardi, F.; Ruffini, M.; Gibertini, G.; Nonnis Marzano, F. The new threat to Italian inland waters from the alien crayfish "gang": The Australian Cherax destructor Clark, 1936. Hydrobiologia 2009, 632, 341-345. [CrossRef]

23. Beatty, S.; Morgan, D.; Gill, H. Role of life history strategy in the colonisation of Western Australian aquatic systems by the introduced crayfish Cherax destructor Clark, 1936. Hydrobiologia 2005, 549, 219-237. [CrossRef]

24. Capinha, C.; Leung, B.; Anastácio, P. Predicting worldwide invasiveness for four major problematic decapods: An evaluation of using different calibration sets. Ecography 2011, 34, 448-459. [CrossRef]

25. Gutekunst, J.; Andriantsoa, R.; Falckenhayn, C.; Hanna, K.; Stein, W.; Rasamy, J.; Lyko, F. Clonal genome evolution and rapid invasive spread of the marbled crayfish. Nat. Ecol. Evol. 2018, 2, 567-573. [CrossRef]

26. Cai, W.; Ma, Z.; Yang, C.; Wang, L.; Wang, W.; Zhao, G.; Geng, Y.; Yu, D.W. Using eDNA to detect the distribution and density of invasive crayfish in the HongheHani rice terrace World Heritage site. PLoS ONE 2017, 12, e0177724. [CrossRef] [PubMed]

27. Harper, K.J.; Anucha, N.P.; Turnbull, J.F.; Bean, C.W.; Leaver, M.J. Searching for a signal: Environmental DNA (eDNA) for the detection of invasive signal crayfish, Pacifastacus leniusculus (Dana, 1852). Manag. Biol. Invasions 2018, 9. in press. [CrossRef]

28. Riascos, L.; Geerts, A.N.; Oña, T.; Goethals, P.; Cevallos-Cevallos, J.; Vanden Berghe, W.; Volckaert, F.A.M.; Bonilla, J.; Muylaert, K.; Velarde, E.; et al. DNA-based monitoring of the alien invasive North American crayfish Procambarus clarkii in Andean lakes (Ecuador). Limnologica 2018, 70, 20-25. [CrossRef]

29. Pereira Almerão, M.; Delaunay, C.; Coignet, A.; Peiró, D.F.; Pinet, F.; Souty-Grosset, C. Genetic diversity of the invasive crayfish Procambarus clarkii in France. Limnologica 2018, 69, 135-141. [CrossRef]

30. Liu, G.; Zhou, L. Population genetic structure and molecular diversity of the red swamp crayfish in China based on mtDNA COI gene sequences. Mitochondrial DNA Part A DNA Mapp. Seq. Anal. 2017, 28, 860-866. [CrossRef] [PubMed]

31. Semenchenko, V.; Lipinskaya, T.; Vilizzi, L. Risk screening of non-native macroinvertebrates in the major rivers and associated basins of Belarus using the Aquatic Species Invasiveness Screening Kit. Manag. Biol. Invasions 2018, 9, 127-136. [CrossRef]

32. Mijošek, T.; Jelić, M.; Mijošek, V.; Maguire, I. Molecular and morphometric characterisation of the invasive signal crayfish populations in Croatia. Limnologica 2017, 63, 107-118. [CrossRef]

33. Lodge, D.M.; Simonin, P.W.; Burgiel, S.W.; Keller, R.P.; Bossenbroek, J.M.; Jerde, C.L.; Kramer, A.M.; Rutherford, E.S.; Barnes, M.A.; Wittmann, M.E.; et al. Risk Analysis and Bioeconomics of Invasive Species to Inform Policy and Management. Ann. Rev. Environ. Resour. 2016, 41, 453-488. [CrossRef]

34. Filipe, A.F.; Quaglietta, L.; Ferreira, M.; Magalhães, M.F.; Beja, P. Geostatistical distribution modelling of two invasive crayfish across dendritic stream networks. Biol. Invasions 2017, 19, 2899-2912. [CrossRef]

35. Ghia, D.; Fea, G.; Sacchi, R.; Di Renzo, G.; Garozzo, P.; Marrone, M.; Piccoli, F.; Porfirio, S.; Santillo, D.; Salvatore, B.; et al. Modelling environmental niche for the endangered crayfish Austropotamobius pallipes complex in northern and central Italy. Freshw. Crayfish 2013, 19, 189-195.

36. Moreira, F.; Ascensão, F.; Capinha, C.; Rodrigues, D.; Segurado, P.; Santos-Reis, M.; Rebelo, R. Modelling the risk of invasion by the red-swamp crayfish (Procambarus clarkii): Incorporating local variables to better inform management decisions. Biol. Invasions 2014, 17, 1-13. [CrossRef]

37. Usio, N.; Nakajima, H.; Kamiyama, R.; Wakana, I.; Hiruta, S.; Takamura, N. Predicting the distribution of invasive crayfish (Pacifastacus leniusculus) in a Kusiro Moor marsh (Japan) using classification and regression trees. Ecol. Res. 2006, 21, 271-277. [CrossRef]

38. Capinha, C.; Anastácio, P.; Tenedório, J.A. Predicting the impact of climate change on the invasive decapods of the Iberian inland waters: An assessment of reliability. Biol. Invasions 2012, 14, 1737-1751. [CrossRef]

39. Capinha, C.; Anastácio, P. Assessing the environmental requirements of invaders using ensembles of distribution models. Divers. Distrib. 2011, 17, 13-24. [CrossRef] 
40. Capinha, C.; Larson, E.R.; Tricarico, E.; Olden, J.D.; Gherardi, F. Effects of Climate Change, Invasive Species, and Disease on the Distribution of Native European Crayfishes. Conserv. Biol. 2013, 27, 731-740. [CrossRef] [PubMed]

41. Feria, T.P.; Faulkes, Z. Forecasting the distribution of Marmorkrebs, a parthenogenetic crayfish with high invasive potential, in Madagascar, Europe, and North America. Aquat. Invasions 2011, 6, 55-67. [CrossRef]

42. Larson, E.R.; Olden, J.D. Using avatar species to model the potential distribution of emerging invaders. Glob. Ecol. Biogeogr. 2012, 21, 1114-1125. [CrossRef]

43. Nieto-Lugilde, D.; Maguire, K.C.; Blois, J.L.; Williams, J.W.; Fitzpatrick, M.C. Multiresponse algorithms for community-level modelling: Review of theory, applications, and comparison to species distribution models. Methods Ecol. Evol. 2018, 9, 834-848. [CrossRef]

44. Dunning, J.B.; Stewart, D.J.; Danielson, B.J.; Noon, B.R.; Root, T.L.; Lamberson, R.H.; Stevens, E.E. Spatially explicit population models: Current forms and future uses. Ecol. Appl. 1995, 5, 3-11. [CrossRef]

45. Rubenson, E.S.; Olden, J.D. Dynamism in the upstream invasion edge of a freshwater fish exposes range boundary constraints. Oecologia 2017, 184, 453-467. [CrossRef]

46. Acosta, C.A.; Perry, S.A. Spatially explicit population responses of crayfish Procambarus alleni to potential shifts in vegetation distribution in the marl marshes of Everglades National Park, USA. Hydrobiologia 2002, 477, 221-230. [CrossRef]

47. Hansen, G.J.A.; Tunney, T.D.; Winslow, L.A.; Wander Zanden, M.J. Whole-lake invasive crayfish removal and qualitative modeling reveal habitat-specific food web topology. Ecosphere 2017, 8, e01647. [CrossRef]

48. Gonçalves, V.; Gherardi, F.; Rebelo, R. Modelling the predation effects of invasive crayfish, Procambarus clarkii (Girard, 1852), on invasive zebra mussel, Dreissena polymorpha (Pallas, 1771), under laboratory conditions. Ital. J. Zool. 2016, 83, 59-67. [CrossRef]

49. Yarra, A.N.; Magoulick, D.D. Modelling effects of invasive species and drought on crayfish extinction risk and population dynamics. Aquat. Conserv.. under press. [CrossRef]

50. Sánchez, I.A.; Angeler, D.A. A conceptual model of exotic crayfish (Procambarus clarkii) effects on charophyte propagule banks in wetlands. Rev. Latinoame. Recur. Nat. 2006, 2, 17-23.

51. Messager, M.L.; Olden, J.D. Individual-based models forecast the spread and inform the management of an emerging riverine invader. Biodivers. Res. 2018, 24, 1816-1829. [CrossRef]

52. Todd, C.R.; Whiterod, N.; Raymond, S.M.C.; Zukowski, S.; Asmus, M.; Todd, M.J. Integrating fishing and conservation in a risk framework: A stochastic population model to guide the proactive management of a threatened freshwater crayfish. Aquat. Conserv. Mar. Freshw. Ecosyst. 2018, 28, 954-968. [CrossRef]

53. Martelloni, G.; Bagnoli, F.; Libelli, S.M. A dynamical population modeling of invasive species with reference to the crayfish Procambarus clarkii. Theor. Biol. Forum 2012, 105, 47-69. [PubMed]

54. Almeida, P.M. Evaluation of the Exploitation Potential of Red Swamp Crayfish (Procambarus clarkii) in Portugal; Universidade Nova de Lisboa: Lisbon, Portugal, 2013.

55. Anastácio, P.M.; Frias, A.F.; Marques, J.C. CRISP-crayfish rice integrated system of production. 1. Modelling rice (Oryza sativa) growth and production. Ecol. Model. 1999, 123, 17-28. [CrossRef]

56. Anastácio, P.M.; Nielsen, S.N.; Marques, J.C. CRISP-crayfish rice integrated system of production. 2. Modelling crayfish (Procambarus clarkii) population dynamics. Ecol. Model. 1999, 123, 5-16. [CrossRef]

57. Anastácio, P.M.; Nielsen, S.N.; Marques, J.C.; Jørgensen, S.E. Integrated production of crayfish and rice: A management model. Ecol. Eng. 1995, 4, 199-210. [CrossRef]

58. Franklin, T.W.; McKelvey, K.S.; Golding, J.D.; Mason, D.H.; Dysthe, J.C.; Pilgrim, K.L.; Squires, J.R.; Aubry, K.B.; Long, R.A.; Greaves, S.E.; et al. Using environmental DNA methods to improve winter surveys for rare carnivores: DNA from snow and improved noninvasive techniques. Biol. Conserv. 2019, 229, 50-58. [CrossRef]

59. Schnell, I.B.; Bohmann, K.; Schultze, S.E.; Richter, S.R.; Murray, D.C.; Sinding, M.H.S.; Bass, D.; Cadle, J.E.; Campbell, M.J.; Dolch, R.; et al. Debugging diversity-A pan-continental exploration of the potential of terrestrial blood-feeding leeches as a vertebrate monitoring tool. Mol. Ecol. Resour. 2018, 18, 1282-1298. [CrossRef]

60. Bergman, P.S.; Schumer, G.; Blankenship, S.; Campbell, E. Detection of Adult Green Sturgeon Using Environmental DNA Analysis. PLoS ONE 2016, 11, e0153500. [CrossRef]

61. Laramie, M.B.; Pilliod, D.S.; Goldberg, C.S. Characterizing the distribution of an endangered salmonid using environmental DNA analysis. Biol. Conserv. 2015, 183, 29-37. [CrossRef] 
62. Doi, H.; Katano, I.; Sakata, Y.; Souma, R.; Kosuge, T.; Nagano, M.; Ikeda, K.; Yano, K.; Tojo, K. Detection of an endangered aquatic heteropteran using environmental DNA in a wetland ecosystem R. Soc. Open sci. 2017, 4, 170568. [CrossRef] [PubMed]

63. Thomsen, P.F.; Willerslev, E. Environmental DNA-An emerging tool in conservation for monitoring past and present biodiversity. Biol. Conserv. 2015, 183, 4-18. [CrossRef]

64. Nukazawa, K.; Hamasuna, Y.; Suzuki, Y. Simulating the Advection and Degradation of the Environmental DNA of Common Carp along a River. Environ. Sci. Technol. 2018, 52, 10562-10570. [CrossRef]

65. Deiner, K.; Altermatt, F. Transport distance of invertebrate environmental DNA in a natural river. PLoS ONE 2014, 9, e88786. [CrossRef]

66. Thomsen, P.F.; Kielgast, J.; Ivesen, L.L.; Wiuf, C.; Rasmussen, M.; Golbert, M.T.P.; Orlando, L.; Willerslev, E. Monitoring endangered freshwater biodiversity using environmental DNA. Mol. Ecol. 2012, 21, 2565-2573. [CrossRef]

67. Dunn, N.; Priestley, V.; Herraiz, A.; Arnold, R.; Savolainen, V. Behavior and season affect crayfish detection and density inference using environmental DNA. Ecol. Evol. 2017, 7, 7777-7785. [CrossRef] [PubMed]

68. Sigsgaard, E.E.; Carl, H.; Møller, P.R.; Thomsen, P.F. Monitoring the near-extinct European weather loach in Denmark based on environmental DNA from water samples. Biol. Conserv. 2014, 183, 46-52. [CrossRef]

69. Smart, A.S.; Weeks, A.R.; van Rooyen, A.R.; Moore, A.; McCarthy, M.A.; Tingley, R. Assessing the cost-efficiency of environmental DNA sampling. Methods Ecol. Evol. 2016, 7, 1291-1298. [CrossRef]

70. Ikeda, K.; Doi, H.; Tanaka, K.; Kawai, T.; Negishi, J.N. Using environmental DNA to detect an endangered crayfish Cambaroides japonicus in streams. Conserv. Genet. Resour. 2016, 8, 231-234. [CrossRef]

71. Agersnap, S.; Larsen, W.B.; Knudsen, S.W.; Strand, D.; Thomsen, P.F.; Hesselsøe, M.; Mortensen, P.B.; Vrålstad, T.; Møller, P.R. Monitoring of noble, signal and narrow-clawed crayfish using environmental DNA from freshwater samples. PLoS ONE 2017, 12, e0179261. [CrossRef]

72. Cowart, D.A.; Breedveld, K.G.H.; Ellis, M.J.; Hull, J.M.; Larson, E.R. Environmental DNA (eDNA) applications for the conservation of imperiled crayfish (Decapoda: Astacidea) through monitoring of invasive species barriers and relocated populations. J. Crustacean Biol. 2018, 38, 257-266. [CrossRef]

73. Larson, E.R.; Renshaw, M.A.; Gantz, C.A.; Umek, J.; Chandra, S.; Lodge, D.M.; Egan, S.P. Environmental DNA (eDNA) detects the invasive crayfishes Orconectes rusticus and Pacifastacus leniusculus in large lakes of North America. Hydrobiologia 2017, 800, 173-185. [CrossRef]

74. Geerts, A.N.; Boets, P.; Van den Heedea, S.; Goethals, P.; Van der heydena, C. A search for standardized protocols to detect alien invasive crayfish based on environmental DNA (eDNA): A lab and field evaluation. Ecol. Indic. 2018, 84, 564-572. [CrossRef]

75. Tréguier, A.; Paillisson, J.; Dejean, T.; Valentini, A.; Schlaepfer, M.A.; Roussel, J. Environmental DNA surveillance for invertebrate species: Advantages and technical limitations to detect invasive crayfish Procambarus clarkii in freshwater ponds. J. Appl. Ecol. 2014, 51, 871-879. [CrossRef]

76. Mauvisseau, Q.; Coignet, A.; Delaunay, C.; Pinet, F.; Bouchon, D.; Souty-Grosset, C. Environmental DNA as an efficient tool for detecting invasive crayfishes in freshwater ponds. Hydrobiologia 2018, 805, 163-175. [CrossRef]

77. Dickie, I.A.; Boyer, S.; Buckley, H.L.; Duncan, R.P.; Gardner, P.P.; Hogg, I.D.; Holdaway, R.J.; Lear, G.; Makiola, A.; Morales, S.E.; et al. Towards robust and repeatable sampling methods in eDNA-based studies. Mol. Ecol. Resour. 2018, 18, 940-952. [CrossRef]

78. Deiner, K.; Bik, H.M.; Mächler, E.; Seymour, M.; Lacoursière-Roussel, A.; Altermatt, F.; Creer, S.; Bista, I.; Lodge, D.M.; de Vere, N.; et al. Environmental DNA metabarcoding: Transforming how we survey animal and plant communities. Mol. Ecol. 2017, 26, 5872-5895. [CrossRef]

79. Robinson, C.V.; Webster, T.M.U.; Cable, J.; James, J.; Consuegra, S. Simultaneous detection of invasive signal crayfish, endangered white-clawed crayfish and the crayfish plague pathogen using environmental DNA. Biol. Conserv. 2018, 222, 241-252. [CrossRef]

80. Wittwer, C.; Nowak, C.; Strand, D.A.; Vrålstad, T.; Thines, M.; Stoll, S. Comparison of two water sampling approaches for eDNA-based crayfish plague detection. Limnologica 2018, 70, 1-9. [CrossRef]

81. Bálint, M.; Nowak, C.; Márton, O.; Pauls, S.U.; Wittwer, C.; Aramayo, J.L.; Schulze, A.; Chambert, T.; Cocchiararo, B.; Jansen, M. Accuracy, limitations and cost efficiency of eDNA-based community survey in tropical frogs. Mol. Ecol. Resour. 2018, 18, 1415-1426. [CrossRef] 
82. Crall, A.W.; Newman, G.J.; Jarnevich, C.S.; Stohlgren, T.J.; Waller, D.M.; Graham, J. Improving and integrating data on invasive species collected by citizen scientists. Biol. Invasions 2010, 12, 3419-3428. [CrossRef]

83. Delaney, D.G.; Sperling, C.D.; Adams, C.S.; Leung, B. Marine invasive species: Validation of citizen science and implications for national monitoring networks. Biol. Invasions 2008, 10, 117-128. [CrossRef]

84. Crocetta, F.; Agius, D.; Balistreri, P.; Bariche, M.; Bayhan, Y.K.; Çakir, M.; Ciriaco, S.; Corsini-Foka, M.; Deidun, A.; El Zrelli, R.; et al. New Mediterranean Biodiversity Records (October 2015). Mediterr. Mar. Sci. 2015, 16, 682-702. [CrossRef]

85. Zenetos, A.; Koutsogiannopoulos, D.; Ovalis, P.; Poursanidis, D. The role played by citizen scientists in monitoring marine alien species in Greece. Cah. Biol. Mar. 2013, 54, 419-426.

86. Hein, C.L.; Roth, B.M.; Ives, A.R.; Vander Zanden, M.J. Fish predation and trapping for rusty crayfish (Orconectes rusticus) control: A whole-lake experiment. Can. J. Fish. Aquat. Sci. 2006, 63, 383-393. [CrossRef]

87. Green, N.; Bentley, M.G.; Stebbing, P.; Andreou, D.; Britton, R. Trapping for invasive crayfish: Comparisons of efficacy and selectivity of baited traps versus novel artificial refuge traps. Knowl. Manag. Aquat. Ecosyst. 2018, 2018, 9. [CrossRef]

88. Nunes, A.L.; Hoffman, A.C.; Zengeya, T.A.; Measey, G.J.; Weyl, O.L.F. Red swamp crayfish, Procambarus clarkii, found in South Africa 22 years after attempted eradication. Aquat. Conserv. Mar. Freshw. Ecosyst. 2017, 27, 1334-1340. [CrossRef]

89. Rudnick, D.A.; Hieb, K.; Grimmer, K.F.; Resh, V.H. Patterns and processes of biological invasion: The Chinese mitten crab in San Francisco Bay. Basic Appl. Ecol. 2003, 4, 249-262. [CrossRef]

90. Gherardi, F.; Aquiloni, L.; Diéguez-Uribeondo, J.; Tricarico, E. Managing invasive crayfish: is there a hope? Aquat. Sci. 2011, 73, 185-200. [CrossRef]

91. Thiel, M.; Breithaupt, T. Chemical communication in crustaceans: Research challenges for the twenty-first century. In Chemical Communication in Crustaceans; Breithaupt, T., Thiel, M., Eds.; Springer: New York, NY, USA, 2011.

92. Holdich, D.M.; Pöckl, M. Invasive crustaceans in European inland waters. In Biological Invaders in Inland Waters: Profiles, Distribution, and Threats; Gherardi, F., Ed.; Springer: Dordrecht, The Netherlands, 2007; pp. 29-75.

93. Sibley, P. Signal crayfish management in the River Wreake catchment. In Proceedings of the Crayfish conference, Leeds, UK, 26-27 April 2000; pp. 95-108.

94. Peters, J.; Kreps, T.; Lodge, D.M. Assessing the Impacts of Rusty Crayfish (Orconectes rusticus) on Submergent Macrophytes in a North-Temperate U.S. Lake Using Electric Fences. Am. Midl. Nat. 2008, 159, 287-297. [CrossRef]

95. Peay, S.; Dunn, A.M.; Kunin, W.E.; McKimm, R.; Harrod, C. A method test of the use of electric shock treatment to control invasive signal crayfish in streams. Aquat. Conserv. Mar. Freshw. Ecosyst. 2015, 25, 874-880. [CrossRef]

96. Frings, R.M.; Vaeßen, S.C.K.; Groß, H.; Roger, S.; Schüttrumpf, H.; Hollert, H. A fish-passable barrier to stop the invasion of non-indigenous crayfish. Biol. Conserv. 2013, 159, 521-529. [CrossRef]

97. Dana, E.D.; García-de-Lomas, J.; González, R.; Ortega, F. Effectiveness of dam contruction to contain the invasive crayfish Procambarus clarkii in a mediterranean mountain strem. Ecol. Eng. 2011, 37, 1607-1613. [CrossRef]

98. Kerby, J.L.; Riley, S.P.D.; Kats, L.B.; Wilson, P. Barriers and flow as limiting factors in the spread of an invasive crayfish (Procambarus clarkii) in southern California streams. Biol. Conserv. 2005, 126, 402-409. [CrossRef]

99. Elvira, B.; Nicola, G.C.; Almodovar, A. Pike and red swamp crayfish: A new case of predator-prey relationship between aliens in central Spain. J. Fish Biol. 1996, 48, 437-446.

100. Aquiloni, L.; Brusconi, S.; Cecchinelli, E.; Tricarico, E.; Mazza, G.; Paglianti, A.; Gherardi, F. Biological control of invasive populations of crayfish: The European eel (Anguilla anguilla) as a predator of Procambarus clarkii. Biol. Invasions 2010, 12, 3817-3824. [CrossRef]

101. Hein, C.L.; Vander Zanden, M.J.; Magnuson, J.J. Intensive trapping and increased fish predation cause massive population decline of an invasive crayfish. Freshw. Biol. 2007, 52, 1134-1146. [CrossRef]

102. Stebbing, P.; Longshaw, M.; Scott, A. Review of methods for the management of non-indigenous crayfish, with particular reference to Great Britain. Ethol. Ecol. Evol. 2014, 26, 204-231. [CrossRef] 
103. Longshaw, M.; Bateman, K.S.; Stebbing, P.; Stentiford, G.D.; Hockley, F.A. Disease risks associated with the importation and release of non-native crayfish species in mainland Britain. Aquat. Biol. 2012, 16, 1-15. [CrossRef]

104. Stebbing, P.D.; Longshaw, M.; Taylor, N.; Norman, R.; Lintott, R.; Pearce, F.; Scott, A. Review of Methods for the Control of Invasive Crayfish in Great Britain; Taylor \& Francis: London, UK, 2012; p. 105.

105. Freeman, M.A.; Tumbull, J.F.; Yeomans, W.E.; Bean, C.W. Prospects for management strategies of invasive crayfish populations with an emphasis on biological control. Aquat. Conserv. Mar. Freshw. Ecosyst. 2010, 20, 211-223. [CrossRef]

106. Recsetar, M.S.; Bonar, S.A. Effectiveness of Two Commercial Rotenone Formulations in the Eradication of Virile Crayfish Orconectes virilis. Fish. Manag. 2015, 35, 616-620. [CrossRef]

107. Holdich, D.M.; Gydemo, R.; Rogers, W.D. A review of possible methods for controlling nuisance alien crayfish populations. In Crayfish in Europe as Alien Species. How to Make the Best of a Bad Situation? Gherardi, F., Holdich, D.M., Eds.; A.A. Balkema: Rotterdam, The Netherlands, 1999; p. 301.

108. Dalu, T.; Wasserman, R.J.; Jordaan, M.; Froneman, W.P.; Weyl, O.L.F. An Assessment of the Effect of Rotenone on Selected Non-Target Aquatic Fauna. PLoS ONE 2015, 10, e0142140. [CrossRef] [PubMed]

109. Finlayson, B.J.; Somer, W.L.; Vinson, M.R. Rotenone toxicity to rainbow trout and several mountain stream insects. N. Am. J. Fish. Manag. 2010, 30, 102-111. [CrossRef]

110. Billman, H.G.; Kruse, C.G.; St-Hilaire, S.; Koel, T.M.; Arnold, J.L.; Peterson, C.R. Effects of rotenone on Columbia spotted frogs Rana luteiventris during field applications in lentic habitats of south western Montana. N. Am. J. Fish. Manag. 2012, 32, 781-789. [CrossRef]

111. Mangum, F.A.; Madrigal, J.L. Rotenone effect on aquatic macroinvertebrates of the Strawberry River, Utah: A five-year summary. J. Freshw. Ecol. 1999, 14, 125-135. [CrossRef]

112. Melaas, C.L.; Zimmer, K.D.; Butler, M.G.; Hanson, M.A. Effects of rotenone on aquatic invertebrate communities in prairie wetlands. Hydrobiologia 2001, 459, 177-186. [CrossRef]

113. Vinson, M.R.; Dinger, E.C.; Vinson, D.K. Piscicides and invertebrates: After 70 years, does anyone really know? Fisheries 2010, 35, 61-71. [CrossRef]

114. Kjærstad, G.; Arnekleiv, J.V. Effects of rotenone treatment on lotic invertebrates. Int. Rev. Hydrobiol. 2011, 96, 58-71. [CrossRef]

115. Peay, S.; Hiley, P.D.; Collen, P.; Martin, I. Biocide treatment of ponds in Scotland to eradicate signal crayfish. Bull. Fr. Pèche Piscic. 2006, 380-381, 1363-1379. [CrossRef]

116. Bills, T.D.; Marking, L.L. Control of nuisance populations of crayfish with traps and toxicants. N. Am. J. Aquic. 1988, 50, 103-106. [CrossRef]

117. Cecchinelli, E.; Aquiloni, L.; Maltagliati, G.; Orioli, G.; Tricarico, E.; Gherardi, F. Use of natural pyrethrum to control the red swamp crayfish Procambarus clarkii in a rural district of Italy. Pest Manag. Sci. 2012, 68, 839-844. [CrossRef]

118. Cook, M.E.; Moore, P.A. The effects of the herbicide metolachlor on agonistic behavior in the crayfish, Orconectes rusticus. Arch. Environ. Contam. Toxicol. 2008, 55, 94-102. [CrossRef]

119. Peay, S.; Dunn, A.M. The behavioural response of the invasive signal crayfish Pacifastacus leniusculus to experimental dewatering of burrows and its implications for eradication treatment and management of ponds with crayfish. Ethol. Ecol. Evol. 2014, 26, 277-298. [CrossRef]

120. Gherardi, F.; Angiolini, C. Eradication and control of invasive species. In Biodiversity Conservation and Habitat Management, Encyclopedia of Life Support Systems (EOLSS); Gherardi, F., Gualtieri, M., Corti, C., Eds.; Eolss: Oxford, UK, 2004; pp. 271-299.

121. Gherardi, F.; Holdich, D.M.E. Crayfish in Europe as Alien Species. How to Make the Best of a Bad Situation? A.A. Balkema: Rotterdam, The Netherlands, 1999.

122. Corkum, L.D.; Belanger, R.M. Use of chemical communication in the management of freshwater aquatic species that are vectors of human diseases or are invasive. Gen. Comp. Endocrinol. 2007, 153, 401-417. [CrossRef]

123. Stebbing, P.D.; Watson, G.J.; Bentley, M.G.; Fraser, D.; Jennings, R.; Rushton, S.P.; Sibley, P.J. Reducing the threat: The potential use of pheromones to control invasive signal crayfish. Bull. Fr. Peche Piscic. 2003, 370-371, 219-224. [CrossRef]

124. Aquiloni, L.; Gherardi, F. The use of sex pheromones for the control of invasive populations of the crayfish Procambarus clarkii: A field study. Hydrobiologia 2010, 649, 249-254. [CrossRef] 
125. Stebbing, P.D.; Watson, G.J.; Bentley, M.G.; Fraser, D.; Jennings, R.; Rushton, S.P.; Sibley, P.J. Evaluation of the Capacity of Pheromones for Control of Invasive Non-Native Crayfish; Natural England: Peterborough, UK, 2004.

126. Stebbing, P.D.; Watson, G.J.; Bentley, M.G.; Fraser, D.; Jennings, R.; Rushton, S.P.; Sibley, P.J. Evaluation of the Capacity of Pheromones for Control of Invasive Non-Native Crayfish; Natural England: Peterborough, UK, 2005.

127. Ventura, T.; Sagi, A. The insulin-like androgenic gland hormone in crustaceans: From a single gene silencing to a wide array of sexual manipulation-based biotechnologies. Biotechnol. Adv. 2012, 30, 1543-1550. [CrossRef] [PubMed]

128. Rosen, O.; Manor, R.; Weil, S.; Aflalo, E.D.; Bakhrat, A.; Abdu, U.; Sagi, A. An Androgenic Gland MembraneAnchored Gene Associated with the Crustacean Insulin-Like Androgenic Gland Hormone. J. Exp. Biol. 2013, 216, 2122-2128. [CrossRef] [PubMed]

129. Sagi, A.; Manor, R.; Ventura, T. Gene silencing in crustaceans: From basic research to biotechnologies. Genes 2013, 4, 620-645. [CrossRef] [PubMed]

130. Manfrin, C.; Peruzza, L.; Bonzi, L.C.; Pallavicini, A.; Giulianini, P.G. Silencing two main isoforms of crustacean hyperglycemic hormone $(\mathrm{CHH})$ induces compensatory expression of two $\mathrm{CHH}$-like transcripts in the red swamp crayfish Procambarus clarkii. Invertebr. Surviv. J. 2015, 12, 29-37.

131. Manfrin, C.; Piazza, F.; Cocchietto, M.; Antcheva, N.; Masiello, D.; Franceschin, A.; Peruzza, L.; Bonzi, L.C.; Mosco, A.; Guarnaccia, C.; et al. Can peptides be orally-delivered in crustaceans? The case study of the Crustacean Hyperglycaemic Hormone in Procambarus clarkii. Aquaculture 2016, 463, 209-216. [CrossRef]

132. Lodge, D.M.; Williams, S.; Maclsaac, H.J.; Hayes, K.R.; Leung, B.; Reichard, S.; Mack, R.N.; Moyle, P.B.; Smith, M.; Andow, D.A.; et al. Biological invasions: Recommendations for U.S. policy and management. Ecol. Appl. 2006, 16, 2035-2054. [CrossRef]

133. Piazza, F.; Aquiloni, L.; Peruzza, L.; Manfrin, C.; Simi, S.; Marson, L.; Edomi, P.; Giulianini, P.G. Managing of Procambarus clarkii by X-ray sterilisation of males: Cytological damage to gonads. Micron 2015, 77, 32-40. [CrossRef]

134. Giglio, A.; Manfrin, C.; Zanetti, M.; Aquiloni, L.; Simeon, E.; Bravin, M.K.; Battistella, S.; Giulianini, P.G. Effects of X-ray irradiation on haemocytes of Procambarus clarkii (Arthropoda: Decapoda) males. Eur. Zool. J. 2018, 85, 26-35. [CrossRef]

135. Aquiloni, L.; Zanetti, M. Integrated Intensive Trapping ANS SMRT Approach for the Control of Procambarus Clarkii: The Casette Case Study; European Commission: Luxembourg, 2014; pp. 113-116.

136. Gliglio, A. Personal communication. Unpublished work.

137. Johovicć, I.; Verrucchi, C.; Inghilesi, A.F.; Scapini, F.; Tricarico, E. Manual removal of males' gonopods and reproductive potential in the Red Swamp Crayfish, Procambarus clarkii. In Proceedings of the 10th International Conference on Biological Invasions, Dun Laoghaire, Ireland, 3 September 2018.

138. Aquiloni, L.; Becciolini, A.; Berti, R.; Porciani, S.; Trunfio, C.; Gherardi, F. Managing invasive crayfish: Use of X-ray sterilisation of males. Freshw. Biol. 2009, 54, 1510-1519. [CrossRef]

139. Holdich, D.M.; Reynolds, J.D.; Souty-Grosset, C.; Sibley, P.J. A review of the ever increasing threat to European crayfish from non-indigenous crayfish species. Knowl. Manag. Aquat. Ecosyst. 2009, 11, 394-395. [CrossRef]

140. Hudina, S.; Kutleša, P.; Trgovčić, K.; Duplić, A. Dynamics of range expansion of the signal crayfish (Pacifastacus leniusculus) in a recently invaded region in Croatia Aquat. Invasions 2017, 12, 67-75. [CrossRef]

(C) 2019 by the authors. Licensee MDPI, Basel, Switzerland. This article is an open access article distributed under the terms and conditions of the Creative Commons Attribution (CC BY) license (http://creativecommons.org/licenses/by/4.0/). 